\section{DÉRIVE POÉtICA E OBJEÇÁO CULTURAL: \\ DA BOEMIA PARISIENSE a MárIO dE ANDRADE}

Nicolau Sevcenko

FFLCH/História
Universidade de Sāo Paulo

Resumio

A partír de um panorama $e$ de articulaçōes entre os processos de reubarnizaçōes das cidades de Paris e São Paulo e as experiências poéticas de fins do século XIX e primeiras décadas do século XX a poesia de Mário de Andrade é lida na chave da tradiçăo do projeto da boemia parisiense iniciado pela dérive de Jarry Picasso eApollinaire. Essa experiência de errància é diferente da flaneric baudelairiana. Ela e difusa por toda a superficie da cidade e de seus arrabaldes e turva a identidade de quem a pratica, contrariamente a flancrie, que se realiza no circuito circunscrito das arcadas e dos bulevares pansienses, envolvendo um público Enquanto aflânerie confunde-se com um gesto visual, a errância comporta um gesto existencial na sua plenitude.

\section{Abstract}

After beginning with a general overview and establishing the connections between the reurbanization of the cities of Paris and Sào Paulo and the poetic experiments of the late ninetecnth and carly twentieth centuries, Mário de Andrades poetry is then read in light of the tradition of the Parisian bohemian project initiated by Jarry. Picasso, and Apollinaires derive. An experience of drifting that differs from Baudelairean flànerie, dérive stretches across the entirc surface of the city and its outskirts and muddles the identity of its practitioners, while fanerie takes place in the restricted space of the Parisian arcades and boulevards, among a homogeneous public, oud usually with a male protagorist. While flanerie is associated with visual gesture, driffing comprises a fully existential gesture.
Keywords

Poetry,

dérive,

flanerie,

city,

Mário de

Andrade.
Tenho os pés chagados nos espinhos das calçadas... Higienópolis!... As Babilônias dos meus desejos baixos... Casas nobres de estilo... Enriqueceres em tragédias Mas a noite é toda um véu-de-noiva ao luar! [...]

- Về? Estas paragens trevas de silêncio...

Nada de asas, nada de alegria... A Lua...

A rua toda nua... As casas sem luzes.,

E a mirra dos martírios inconscientes... L...

(Mário de Andrade, Paulicéia desvairada, 1922)'

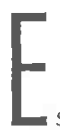

tipo bem peculiar de experiência urbana. Seu sentido nesse contexto é menos metafórico que literal. A imagem se refere ao inchaço e às escoriaçōes provocadas pela perambulaçāo compulsiva, por sobre a rugosidade áspera e as intercorrentes áreas danificadas das calçadas e pavimentos das ruas. Essa errância persistente, obsessiva, que esquadrinha todos os recantos e desvāos da cidade, sem destino certo, sem objetivo definido, sem áreas de preferência ou expectativas prévias, não tem obviamentę também um fim previsto nem sugere qualquer conclusāo definitiva. Num certo sentido, o que ocorre com os pés submetidos a essa itinerância frenética tende a acontecer também com a mente e o sistema nervoso: submetidos a todo tipo de impressāo, choques, sustos, longos momentos de tédio entrecortados por repentinas variaçōes de registro mental e sensorial, diferentes escalas de proporçōes, ritmos e angulaçōes, instantes de solidāo e de compressāo maciça, modificaçōes de temperatura, de contexto social, topográfico e espacial, de atividades e disposiçōes psicológicas, o conjunto do corpo e do espírito precisa se reformular, recondicionar e reinvestir de projetos a cada circunstância e em toda encruzilhada. Trata-se, pois, de uma experiência árdua, angustiada, dolorosa. O enigma então é entender por que ela é compulsiva?

Antes de mais nada, é preciso distinguir o quanto essa experiēncia é dilerente

daquela outra, a do flâneur, tāo bem descrita por Baudelaire e pelos comentários de Walter Benjamin. A flânerie ocorre no circuito circunscrito e conspicuo das

Texto apresentado na mesa-redonda sobre "Cidade, cidadania, modernidade e cultura", no Simpósio Internacional "Origens das Políticas Urbanas Modernas: Europa e América Latina, Empréstimos e Traduçōes", organizado pelo Instituto de Pesquisa e Planejamento Urbano e regional da Universidade Federal do Rio de Janeiro (IPPUR/JFRJ), pelo Centre de Sociologie Urbaine (CSU/ CNRS) e pela Associaçāo Nacional de Pós-Graduaçāo cm Planejamento Urbano e Regional (ANPUR), em ltamontes, Minas Gerais, a 30 de Agosto de 1994

' Todas as citaçōes de Mário de Andrade proceden de Pocsias completas, São Paulo, Circulo do Livro, 1976 
arcadas e dos bulevares parisienses, envolve um público relativamente homogêneo e comporta sobretudo uma experiência de gozo visual, de contemplaçāo erutizada, a partir de uma posição de segurança da identidade, do local e do domínio dos códigos de sociabilidade por parte do seu protagonista, normalmente do dos masculino. A dérive é coisa bem diversa. Ela nāo tem centralidade, é difusa por toda a superfície da cidade e de seus arrabaldes. Ela força o desenraizamento e turva a identidade de quem a pratica. Ela nem parte de uma visão unitária da cidade, nem pretende atingir esse resultado, estando desde sempre encerrada opacidade do imprevisivel, do errático, do instável e do perigoso. Ela não é um ato de gozo, sua substância vibra em ressonância com os aspectos mais extremos e dramáticos da vida nas cidades, assim como os mais monótonos, vulgares e inexpressivos. Mais do que uma experiência visual, ela comporta um gesto existencial na sua plenitude. Não sendo um modo de contemplaçāo, ela caracteriza sobretudo um sistema de aprendizagem, uma apercepção, uma ampliação e aprofundamento da consciência contextual, da requalificaçāo da vida e do sèr humano no âmbito das grandes cidades, a busca enfim de uma dimensão afetiva, de dotar de uma ancoragem. na memória aquilo que lhes é dado como a voragem hostil, imensa e inapreensível no interior da qual cada um é como uma molécula demarcada, mas indistinta e vazia.

O conceito de dérive tal como usado atualmente na crítica procede de sua definiçāo dentre os membros do Situacionismo, primeiramente através de Ivan Chtcheglov em 1953 e depois Guy Debord em 55. Debord teorizou mais amplamente o conceito, caracterizando a dérive como "o encontro fugitivo de várias atmosferas à medida que se vagueia casualmente pela cidade" 2 A dimensão aferiva de que os situacionistas pretendiam reinvestir o espaço urbano foi denominada de psicogeográfica. Mas nāo se entenda aí uma geografia normativa, cartográfica ou sọb quaisquer de suas conotaçōes redutivas. O que se busca é uma relaçāo interativa e substantiva com o espaço urbano, suas circunstâncias condicionantes, seus elementos integrantes, suas atmosferas psicológicas e seus códigos socioculturais. Ao contrário da tentativa de reduzir a face da cidade a um plano racional, inteligivel e integrado, o objetivo é mergulhar na densidade irredutíve o frêmito e da heterogeneidade urbana, acrescentando-lhes ainda um novo pulso interferente. Por isso, segundo um outro teórico, Michel de Certeau, nāo é a visāo orgânica, a partir do alto, o "olhar panóptico", o mais apropriado para captar a latência do bulício metropolitano, mas,

Ao contrário, é por baixo - "em baixo" - no limiar em que a visibilidade termina, que o praticante comum da cidade reside, A matéria-prima desse experimento sāo os andarilhos, os Wandersmanner, cujos corpos formam a escrita cursiva eo tracado de um " "seno" os andarihos, os sem lerem. Esses praticantes lançam mào de espaços que nāo sāo auto-ra que elescreven que têm deles é tãu cego quanto aquele de um corpo por outro corpo amado. Os caminhos que

${ }^{2}$ C. Hollevoet; K. Jones; T. Nye, The Power of the City/The City of Power, New York, The witney Museum of Art, 1992, p. 32 . se interconectam nessa rede, poeinas estranhos dos quais cada corpo é um elemento submerso por dentre muitos outros, impedem a leitura. Tudo acontece como se alguma forma de cegueira fosse a marca registrada dos processos pelos quais a cidade é organizada. As redes dessas escritas entrecruzadas e em avanço continuo formam uma história múltipla, não têm criador ou espectador sendo compostas de fragmentos de trajetórias e alteraçōes de espaços: em relaçāo às representacōes, elas permanecem dia após dia, indefinidamente, algo outro [..] Em meio a essa totalidade, gostaria de indicar os processos que são estranhos ao espaço visual "geométrico" ou "geogréfico" das

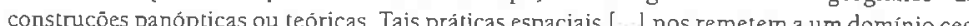
con opaco da cide habiad ou a texto claro da cidade planejada e legivel. ${ }^{3}$

O que Michel de Certeau nos ilustra aqui é o modo peculiar como a capital moderna estabelece experiências simultâneas e intervenientes, que escapam e iludem os procedimentos do lógos gestor, incrementando ademais o manancial de possibilidades postas para a interaçāo social e a inventividade cultural coletiva Nessa linha, a prodigiosa riqueza dos processos históricos urbanos deve ser buscada sobretudo como estando inscrita na materialidade e na dirnensāo humana dos espaços da cidade. Essa vibraçāo inscrita demanda o esquadrinhamento arqueológico das superfícies, dos interiores e das áreas abertas, onde a história pode ser resgatada como topografia, como toponímia e como cultura material, Nas metrópoles, o espaço retém o tempo, assim como as evocaçōes do passado repõem a carga afetiva que a razāo planejadora extorquiu das pedras. É com esse espírito que Walter Benjamin revisita a Paris das arcadas. É investido dele também que Frederic Jameson desenvolve o conceito teórico-político de "cognitive mapping", através do qual estabelece a preeminência da dimensāo topográfica na apreensāo da modernidade e propōe a reapropriação do espaço urbano pelos cidadãos, a quem a gestão técnica destituiu de qualquer inserção densa de memória e sentimento humano no corpo fluido da cidade. Eis como ele o formula, fértil de esperanças latentes:

Um modelo de cultura política adequado para a nossa própria situaçāo, necessariament colocará questōes espaciais como sua preocupaçāo organiżacional fundamental. Eu portanto vou definir provisoriamente $[\ldots]$ uma estética do mapeamento cognitivo $[. .$.$] A cidade alienada$ sobretudo um espaço no qual as pessoas são incapazes de mapear ou suas próprias posiçōes ou a totalidade urbana na qual se encontram [...] A desalienaçāo na cidade tradicional envolve, pois, a reconquista prática de um sentido de lugar e a construção ou reconstruçāo de um conjunto articulado que possa ser mantido na memoria e que o sujeito individual possa mapear e remapea ao longo dos momentos de trajetorias móveis c alternativas.

A origem da lírica moderna, com a publicaçāo simultânea de Alcools por Apollinaire e Les Pâques de New York por Blaise Cendrars, em 1913, assinala já no seu nascimento

"Michel de Certeau, "Practices of Space", in In Signs, a semiotics reader, Marshall Blonsky (ed), Oxford, Basil blackwell, 1985, pp. 124-6,

"F. Jameson, "The Cultural Logic of Late Capitalism" in Postmodernism, or the Cultural Logic of Late Capitalism, Durham, Duke University Press, 1991 
o papel seminal que a experiência da dérive teria na definição da imaginação artística do século XX. No poema de abertura de seu livro, "Zona", Apollinaire traduz em versos livres um périplo longo e sem destino do poeta pelas ruas de Paris. O percurso vai do centro para a periferia, retornando depois no sentido oposto. Assim, o artista parte logo ao alvorecer das áreas conspicuas e urbanizadas em direção ao subúrbio populoso, pobre, opressivo e promiscuo, onde os magotes de imigrantes se amontoam nas pensões baratas, nos bares e nas encruzilhadas do bairros operários. A palavra "zona" vai se revelando assim em todos os seus múltiplos sentidos. Na sua acepção mais óbvia ela remete à degradação, à prostituição e às compulsôes do desejo e do vício. Mas nesse periodo ela adquire sobretudo uma forte conotação de termo técnico de estratégia militar e dos cálculos geopolíticos, acentuando o modo pelo qual as circunscriçōes territoriais da cidade assinalam também suas clivagens e tensỏes sociais, os "fronts internos". Há mais porém. A origem grega da palavra sugere a auréola circular do Sol, evocando deus Apolo, padroeiro do poeta, reiterando o sentido circular, contínuo e repetitivo da sua peregrinaçâo, sem começo nem fim, que se inicia numa madrugada e conclui na madrugada do dia seguinte, quando já é hora de iniciar novamente a rotação de um tempo cíclico, não linear, não progressivo, não cumulativo, que se consuma como dissipação, como a reiteração compulsiva da busca de completude.

O poema começa com a evocação matinal do novo cenário urbano de Paris, transfigurado pelas tecnologias emergentes que estabeleceram uma estrutura viária de viadutos, estações, tráfico intenso e estruturas metálicas gigantescas, articuladas pelo poeta no paradoxo de uma pastoral mecānica e ruidosa:

Enfim cansaste deste mundo antigo

Pastora ó torre Eilfel o rebanho das pontes bale esta manhā

Chega de viveres na antigüidade grega e romana $[\ldots]$

E o poeta se põe então em movimento, caminhando errático pelas ruas, antigas e novas, algumas recém-surgidas no afã da urbanizaçāo acelerada, sob o impacto dos sinais de comunicação de massas, a publicidade onipresente, os ritmos da pulsação industrial e de energias inéditas que o exaltam como os raios do Sol:

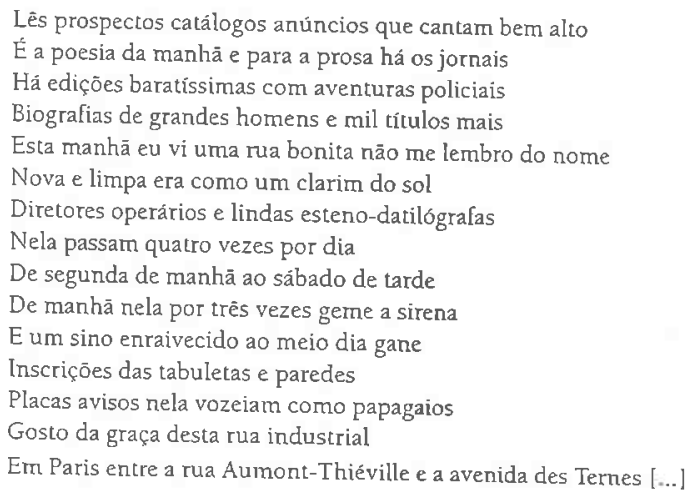

E segue se internando pelos arrabaldes obscuros, repletos de personagens esquálidos e desesperançados, ambientes infectos e cenas deprimentes:

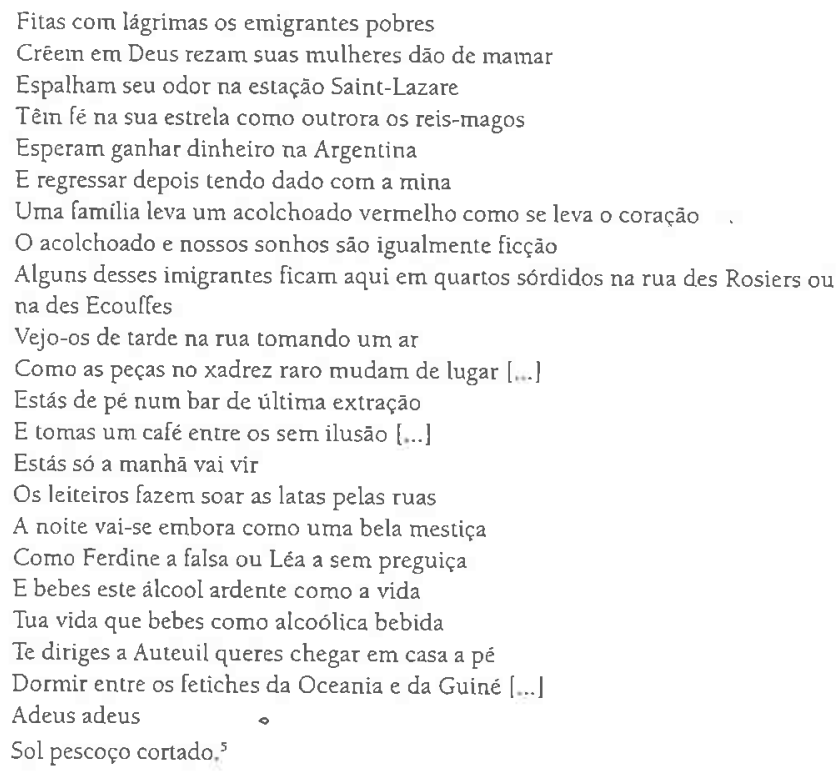

É muito interessante e revelador que Apollinaire conclua o ciclo dessa sua derivaçāo urbana recolhendo-se por "entre os fetiches da Oceania e da Guiné". De fato, a prática sistemática de percorrer os mercados de bugigangas e quinquilharias da cidade, especialmente em busca de esbulhos da exploração colonial dos trópicos, ou despojos de arte ou artesanato popular adquiridos por bagatelas aos imigrantes, fora um hábito novo introduzido junto ao grupo da boemia parisiense por Alfred Jarry. Sobretudo junto de Picasso e às vezes acompanhados de Apollinaire, eles repassavam o Irocadero, - Mercado das Pulgas, as feiras de objetos usados e variedades de Montmartre, em busca de destroços e resíduos de outras culturas nāo-européias, antigas ou atuais, vivas, mortas ou em extinçāo, a partir dos quais pudessem resgatar a intensidade prístina de experiências e ritos culturais que a civilizaçāo burguesa sufocara e extinguira sob seus códigos moralizadores. Também visitavam os parques de diversōes baratas e os cinematógrafos, atividades baseadas nos novos potenciais da eletricidade e voltadas para as massas operárias dos arrabaldes. Foi assim que Jarry, instigado pela convicçāo anarquista que animava o grupo, levou Picasso a descobrir as pinturas naif do Douanier Rousseau, as máscaras africanas no Trocadero, o mercado clandestino de estatuetas

"Guillauine Apollinaire, "Zona" in Escritos de Apollinaire, Traduçāo e notas de Paulo Hecke Filho, Porto Alegre, L\&PMi, 1984, Pp: 199-204 
pré-romanas roubadas ao Louvre, artefatos que combinados com as fortes impressões das diversōes elétricas e do cinema produziriam a quimica explosiva do cubismo.

Não por acaso, a grande obra coletiva do grupo boêmio (exceto Jarry, que morreu em novembro de 1907), incluídos aí Picasso, Apollinaire, Cocteau, Satie e a companhia dos Balés Russos de Diaghliev, foi o Balé Parade. O espetáculo multiartistico destacava as energias frenéticas e os potenciais democráticos que irradiavam das novas metrópoles, incitando o público a abrir-se para a mudança e participar ativamente dos processos de transformação cultural e social. Como indica o título, a peça foi concebida como o desfile de uma troupe circense através da cidade, percorrendo os pontos e as situações mais excitantes que ela apresenta e terminando à porta do circo, onde afinal ninguém do grupo entra, concluindo a encenação do lado de fora, o lado público da cidade a céu aberito. Representado em 1917, no momento mais trágico e nebuloso da Grande Guerra, o balé foi recebido pelo público como um atentado anarquista à moral patriótica que sustentava o esforço de guerra francês, com o público reagindo irado, partindo para o espancamento do elenco e a prisão de alguns dos responsáveis pela montagem.? De fato, o otimismo cheio de esperança na transformação social do grupo boêmio não pôde sobreviver aos efeitos reacionários de propaganda e mobilização da guerra, extinguindo-se com a própria boemia como consequeencia do conflito. O novo momento traria consigo novos imperativos políticos e culturais, lapidarmente resumidos na voz de comando que clamava pelo "retorno à ordem".

Aquele otimismo contudo teve sua razăo de ser. O periodo entre o terço final do século XIX até o inicio da guerra, genericamente conhecido como Belle Êpoque, foi assinalado por drásticos processos de reforma urbana, os quais imprimiram traços indeléveis tanto nas produçōes culturais quanto nas representaçōes da vida social. O ato inaugural desse urbanismo metropolitano foi a abertura do parque de Birkenhead, nas cercanias de Manchester, por encomenda do Parlamento inglês ao arquiteto Paxton, em 1847. Concebido no contexto do movimento reformista animado pela teoria dos miasmas, a intenção da elite política era de que ele atraisse para si os grandes contingentes comprimidos em péssimas condições de higiene e moradia nos bairros proletários, aliviando assim os riscos de epidemias e contaminaçōes ao propiciar ar puro, sol, ăreas verdes e oportunidades de lazer e exercicio para os mais humildes. Ademais, tendo a oportunidade de escapar ao ambiente promiscuo dos cortiços, as famílias podiam garantir a preservação dos padrões de moralidade e decência de seus membros. Paxton foi muito além do previsto e criou um parque monumental, centrado no célebre Crystal Palace, com áreas criteriosamente separadas e definidas para jogos e exercícios, para passeios a pé, a cavalo ou de charrete e para convescotes. O resultado primoroso atraiu gente

R. Shatuck, The Banquet Years, the origins of the avant-garde in France 1885 to World War I, revised edition, New York, Vintage Books, 1968, pp. 187-222; N. Sevcenko, Orfeu cxtatico na metropole,
Sào Paulo, sociedade e cultura nos frementes anos 20, Săo Paulo, Cia, das Letras; 1992 ,

' R. Shead, Music in the 1920s, London, Duckworth, 1976, pp.34-9; E. Brody, Paris, the musical kalcidoscope, 1870-1925, London, Robson Books, 1988, p. 291.

"J. Berger, The Success $\&$ Failure of Picasso, London, Writers and Readers, 1980, pp. 86-102; J. Golding: N. Reid, Leger and Purist Paris. London, The Tate Gallery. 1970, pp. 52-64. de todos os niveis sociais, tornando-se o primeiro parque policlassista moderno, tornando-se o modelo do parque vitoriano e sendo imitado por toda parte, tanto no Reino Unido como no exterior, sendo por exemplo a fonte em que Olmstead se baseou para a criaçāo do Central Park em New York. ${ }^{9}$

A própria capital, Londres, já possuia alguns parques mais antigos como o Hyde Park (1635), o Saint James e o Regent's Park (ambos da primeira metade do século $\mathrm{XIX),} \mathrm{todos} \mathrm{na} \mathrm{aristocrática} \mathrm{zona} \mathrm{oeste} \mathrm{da} \mathrm{cidade} \mathrm{e} \mathrm{por} \mathrm{isso} \mathrm{reservados} \mathrm{ao} \mathrm{usufruto} \mathrm{das}$ elites. Diante do sucesso de Birkenhead, uma série de novos parques populares foi criada, destinados a um uso policlassista: Vauxhall, Ranelagh, Marylebone e outros. Essa rápida proliferaçāo de áreas verdes causou especial impressāo num personagem francês então vivendo como exilado político em Londres, Luís Napoleāo, um anglófilo declarado. Tāo logo ele assumiu o poder na França, vindo a tornar-se Napoleāo III, fez da reforma urbana de Paris uma de suas principais plataformas, nomeando o engenheiro e urbanista barāo de Haussmann para encabeçar o projeto. Atendendo aos propósitos do imperador, Haussmann abre os novos bulevares de circulaçào e arejamento e concebe um complexo sistema de "áreas verdejantes", que se estendiam por quase todas as dimensōes da cidade. O sistema compreendia quatro tipos bem definidos de áreas verdes: os bosques perurbanos, como o de Vincennes e o de Boulogne; os parques intraurbanos fechados, como os de Mountsouris e Buttes-Chaumont; um conjunto de cerca de trinta praças nas áreas de maior concentraçāo e junto aos entroncamentos viários e, por fim, os grandes jardins abertos centrais, o mais célebre dos quais o Champs Élysées. Ademais, o barāo contou com a colaboraçāo dos arquitetos e urbanistas Alphand, Davioud e Hittorf, que se encarregaram dos arranjos paisagisticos e preencheram essas áreas ajardinadas de um mobiliário destinado a dotá-las das maiores comodidades, confortos e garantias de tranqüilidade e segurança. Disseminados pelos parques, praças e jardins foram dispostos bancos e postes de iluminação decorativos, abrigos, quiosques, jornaleiros, docerias, floristas, restaurantes, bancas de brinquedos refrescos e sorvetes, tabacarias, toaletes, coretos, pequenas orquestras e retretas.

O resultado foi surpreendente. Os parques se encheram de gente de toda condiçāo social, tornando-se nāo só áreas de lazer e entretenimento, mas também de consumo, de desfile, de encontros, de convivio, de comer, beber, ouvir música e flertar. Os cronistas, entusiasmados, falavam em "salōes de verdor" e comparavam o convivio diurno na "grande ópera urbana" com os prazeres da vida noturna da cidade. Nesse sentido é preciso destacar o quanto os jardins franceses, ainda que inspirados em fontes inglesas, eram peculiares e essencialmente diferentes. Os jardins ingleses insistiam numa forte evocação rural. Os parques eram povoados de animais do tipo que se encontram nas propriedades agrárias: patos, gansos, cisnes, marrecos, galinhas, coelhos, cavalos e veados; as cercas e casas de conservaçāo eram de feitio rural e os arranjos da vegetação procuravam recriar a rusticidade e os imprevistos da natureza. De acordo com o projeto político do Parlamento inglês, a evocação do campo reintroduziria o espírito da tradiçāo e da autoridade em meio ao caos urbano, reatando os laços rompidos com o passado e 
com o principio da ordem. Em contraste, os jardins franceses eram abertos para a cidade, foram projetados como uma extensão natural do espaço urbano e em especial destinados a atuar como o seu palco principal. Eles, de fato - os intelectuais e cronistas são convictos a esse respeito-, atribuirarn uma notável visibilidade para a vida pública, tornando a cidadania e o usufruto dos direitos à cidade numa prática observada ritualizada todos os dias aos olhos de todos. Mais do que um palco de exibição de status ou consumo, os jardins estimulavam o refinamento da sociabilidade, desenvolvimento das formas de cortesia, convivio, respeito mútuo e para com a coisa pública. Se a reforma atingiu e acentuou a segregação de grande parte da populaçāo pobre da cidade, o que é inegável, também proporcionou uma visibilidade inédita para as virtudes do respeito social e convivio democrático. ${ }^{10}$

Eis, a esse respeito, a descriçāo notávcl que Proust laz do passeio de Odette Swann pelas alamedas do Bois de Boulogne, misturando-se com seu indefectivel séquito masculino por entre os jardins e arvoredos:

1... 1 a Sta. Swann, devido à hora tardia do seu aparecimento, evocava aquele apartamento onde passara uma manhâ tão longa e a que teria de voltar em breve para o almoço; parecia inticar-l he a proximidade com a tranquilidade displicente de seu passcio, semelhante ao que a gente pelo próprio jardim; daquele apartamento poder-se-ia dizer que cla trazia ainda em torno de si a sombra interior e fresca. Mas exatamente por tudo isso, a sua vista mais ainda me dava a sensaço do ar livre e do calor. Tanto mais que, na persuasāo de que, em virtude da liturgia e do sensaçăo quais a Sra. Swann era profundamente versada, estava a sua em virtude da liturgia e dos ritos nos um elo necessário, único $|\ldots|$ O que aumentava cssa impressão de que a estaçāo e à hora por pela avenida do Bois como pela alameda de um jardim de sua propriedate, Swann passeava ignoravam seus häbitos de footing - ter vindo a pés sem caro qupriedade, era - para os que Swann, principalmente com aquele andar quo a pé, sem carro que a seguisse [...] A pé, a Sra. cedido a uma curiosidade de cometer uma eque soberanos que, sem consultar ninuerm, acogante intraçāo às regras do protocolo, como esses de um séquito que nāo ousa formu gala e visitm gala e visitam o saguão, misturando-se por alguns instantes aos outros espectadores.'

O sucesso da experiência contribuiu para que ela losse rapidamente imitada e difundida para quase todas as grandes capitais européias. No Império ÁustroHúngaro, por exemplo, ela foi implementada com requintes pela trinca Otto Wagner, Camille Sitte e Adolf Loos, que tornaram Viena uma referência urbanistica modela e obrigatori. O mesmo sucederia, numa referencia encadeado, com Praga projetos projetos de Max Urban. ${ }^{12}$ Kafka refletiu fortemente o impacto grandioso dessa metamorfose urbana, tornando-a num dos temas chaves de sua obra em textos

${ }^{10}$ Idem, ibidem.

"Marcel Proust, Ả sombra das raparigas $\mathrm{em}$ flor, 2. ed., traduçāo de Mário Quintana, Porto Alegre, Globo, 1960, pp. 168-9.

${ }^{12}$ P. Haiko, "La trilogie vicnnoise: Wagner, Sitte, Loos", in J. Dethier; A. Guiheux (org.) La Villc, art et architecture en Europe 1870-1993, Paris, Centre Pompidou, 1994, pp. 130-3; -P. Krajci, "Le grand
prague idéal de Max Urban", in J. Dechier; A. Guiheux (org.) ibidem, pp. 152-3. como "A Muralha da China", "A Torre de Babel", "O Castelo", "A Colônia Penal", dentre vários outros. Robert de Musil, no seu O homem sem qualidades, nos legou uma imagem esfuziante da Viena dos anos 20, obtida, uma vez mais, da perspectiva do caminhante sem destino, movido pela atração irresistivel do bulício da grande cidade. Sua descrição, logo no início do livro, culmina numa tirada sarcástica sobre dois personagens que querem resistir ao turbilhāo democrático da cidade:

Automóveis emergiam disparando das ruas estreitas e fundas para a rasa claridade das praças. A mancha escura de transeuntes formava fios nevoentos. Onde riscos de velocidade maior cruzavam aquele ritmo negligentes, os fios se adensavam, corriam mais depressa, retornando depois de algumas pulsações ao ritmo regular. Centenas de sons enroscavam-se, produzindo um rumor metálico do qual brotavam pontas isoladas, correndo ao longo de suas beiradas cortantes e recolhendo-se outra vez; saltavam dele lascas de tons claros, que logo sumiam esvoaçantes. Nesse rumor, sem poder defini-lo, alguém que tivesse estado ausente vários anos teria, de olhos fechados, reconhecido a capital do Império, Viera, a Residência As cidades se reconhecem pelo andar, como as pessoas. Abrindo os ollos, o recém chepado deduziria o mesmo da vibraço do movimento nas ruas, muito antes do que qualquer detalhe típico $[. .$.

Como todas as cidades grandes, [Viena] era [eita de irregularidade, mudança, avanço, passo desigual, choque de coisas e acontecimentos e, no meio disso tudo, nontos de silèncio, sem fundo; disso ten de e dissonância de todos os ritmos, como uma bolha fervente pousada nurn recipiente feito da stância duradoura das casas, leis, ordens e tradiçōes históricas.

As duas pessoas que subiam uma rua larga e movimentada nāo tinham naturalmente essa impressāo, Via-se logo que eram de uma camada privilegiada da sociedade, elegantes no vestir, na postura, no modo de conversar; as iniciais dos seus nomes estavam caprichosamente bordadas em sua roupa branca; da mesma forma, sem exibiçāo, mas na fina roupa de baixo da sua consciência, sabiam quem eram, e que seu lugar era ali, na capital e Residência [...] deparamos com o enigma da identidade delcs. Pessoas curiosas freqüentemente encontram esse tipo de enigma nas ruas. A maneira como se resolvern é digna de nota, São esquecidos, caso nos próximos cinqüenta passos nāo consigainos lembrar onde já vimos os dois. ${ }^{13}$

Essa experiência internacional de ampla difusāo de projetos urbanisticos, fossem de padrāo inglês ou francês, encontrou ressonãncia em inúmeras capitais latinoamericanas, refletindo o processo geral de enriquecimento da área em razāo da prosperidade que a revolução científico-tecnológica promoveu no mercado de matérias-primas, na passagem do século. ${ }^{14}$ No caso específico de Sāo Paulo, beneficiária por excelência do prodigioso boom da economia cafeeira, teve especial relevo o papel representado pelo conselheiro Antônio Prado, proprietário das maiores fazendas e dos mais lucrativos negócios associados à cafeicultura, um dos homens mais ricos e poderosos do Brasil e, como de hábito, francófilo, tendo vivido grande parte de sua vida em Paris, para onde retornava ao menos uma vez todo ano. ${ }^{15}$ Ele não só assistiu à metamorfose urbanistica da capital da França,

${ }^{13}$ Robert Musil, O homem sem qualidades, 2, ed., traduçāo de Lya Luft e Carlos Abbenseth, Rio de Janeiro, Nova Fronteira, 1989, pp. 9-10

${ }^{14}$ E. Hobsbawn, The Age of Empire, 1875-1914, London, Weidenfeld and Nicholson, 1987, pp. 56-83. "D. Levi, A familia Prado, São Paulo, Cultura 70, 1974, pp. 187-216. 
como se encheu de entusiasmo por ela, tanto pelo seu efeito sanitário, paisagistico e modernizador, quanto pelo seu efeito político de construção de um espaço público, raiz de uma nova consciência de cidadania.

Animado por essas suas impressōes, ele assumiria a Prefeitura de Săo Paulo, passo simples para quem tinha o total controle da máquina política paulista, mantendo-se no cargo de 1899 a 1911 e desencadeando um projeto de reurbanização que transformaria por completo as feiçōes da cidade, prosseguindo em suas linhas gerais para além do periodo de sua gestão. Ele contrata como seus colaboradores os arquitetos e urbanistas Bouvard e Couchet, ligados a Prefeitura de Paris. Seguindo a inspiração francesa, seu plano se centrou num amplo sistema de parques extra e intraurbanos, praças, jardins e arborização generalizada. Seu projeto concebia um enorme cinturão verde aberto, envolvendo toda a área central da cidade, que partia do exuberante jardim lenotriano do Palácio do Museu do Ipiranga, descia pelos amplos bulevares arborizados das avenidas Pedro le do Estado, desaguava pelas margens ajardinadas do Tamanduateí no imenso Parque D. Pedro Il, aos pés da colina principal no coração da urbe, culminando em grande climax paisagistico na perspectiva monumental do Parque do Vale do Anhangabaú, cortado pelas estruturas metálicas dos viadutos do Chá e de Santa Efigênia e coroado nos seus pontos mais altos pelo novo Teatro Municipal, a sede da Light, o Automóvel Club e o Palacete Prates. O próprio Conselheiro costumava passear com sua familia pelos novos dominios ajardinados, atraindo a populaçāo para as áreas verdes, transmitindo aos circunstantes seu aprendizado parisiense sobre o desfrute das amenidades e as formas elaboradas do convivio democrático no espaço público.

A atmosfera parisiense da cidade era tão evidente, que quando o ex-presidente do Conselho francês Georges Clemenceau aqui esteve, pouco antes da Primeira Guerra, registrou em sua crônica de viagem: "A cidade de São Paulo é tão curiosamente francesa em certos aspectos que, ao longo de toda uma semana, eu não me recordo de ter tido a sensação de que estava no exterior ${ }^{n}{ }^{16} \mathrm{~A}$ taxa espetacular de crescimento urbano da cidade, sem igual no mundo, acrescentavalhe entretanto ao ar europeu, um frenesi típico dos fenômenos sociais bombásticos do mundo subdesenvolvido. ${ }^{17}$ O que deu a outro visitante ilustre, Blaise Cendrars, trazido aqui pelo patrocínio do filho do Conselheiro de que esta "era uma cidade selvagem, como são todas cidades americanas $[\ldots]$ São Paulo era, então, indōmita". O próprio Blaise costumava ironicamente trocar o nome da capital, chamando-a de "Saint-Paul". Ele retornaria várias vezes; sempre sob o patronato de Paulo Prado, entre 1923 e 1928, entregando-se ao impulso de vagar ao léu pelos mais diversos recantos da urbe, sozinho, sem

${ }^{16} \mathrm{H}$. da Silva Bruno, Histórias e tradiçōes da cidade de Sāo Paulo, Rio de Janeiro, José Olympio, 1964 , p. 956

${ }^{17} \mathrm{~N}$. Sevcenko, "São Paulo the quintessential uninhibited Megalopolis as seen by Buise Centars in the $1920 s^{\prime}$, in L. Barker; A. Sutcliffe, Megalopolis, the big city in history, London/New York, MacMillan,
Saint Martin's Press, 1993. tradutor para uma língua que ele nāo conhecia, mas comunicando-se com as pessoas humildes que encontrava pelo caminho. Alguns momentos desses percursos recursivos e encontros fortuitos ficaram fixados nos poemas-instantâneos de Feuilles de route. ${ }^{18}$

Mas seria sobrecudo Mário de Andrade quem iria empreender um esforço sistemático para dar forma poética à tormentosa metamorfose urbana da cidade. "Sāo Paulo! comoçāo da minha vida.../ Galicismo a berrar nos desertos da América!" ("Inspiraçāo"). Não se tratava de celebraçāo, longe disso, ao poeta não escapavam os aspectos mais aflitivos de uma urbanizaçāo comandada pela voracidade de interesses especulativos e indiferente à contrapartida de segregaçāo e violência contra as camadas humildes. Não lhe escapava a maneira pela qual a cosmopolitização acelerada, de recorte europeu, relegou aspectos marcantes da memória, da cultura e da paisagem locais. "Estes meus parques do Anhangabaú ou de Paris/ Onde as tuas águas, onde as mágoas dos teus sapos?/ [...] Onde as tuas bananeiras?/ Onde o teu frio rio encanecido pelos nevoeiros [...]?" ("Anhangabaú"). Mário representava o frēmito intenso dos novos fluxos urbanos pela imagem fluida da dança e dos ritmos sincopados, os mesmos que ilustram o novo dinamismo da cidade, a pulsação repetitiva das novas rotinas mecanizadas e a dissipaçāo aflitiva dos conflitos sociais intensificados.

Grande funçāo ao ar livre!

Bailado de Cocteau com os barulhadores de Russolo!

Opus 1921.

Sāo Paulo é um palco de bailados russos.

Sarabandam a tísica, a ambiçāo, as invejas, os crimes

e também as apoteoses da ilusāo...

Mas o Nijinsky sou eu!

E vem a Morte, minha Karsavina!

Quá, quá, quá! Vamos dançar o fox-trot da desesperança

a rit, a rir dos nossos desiguais! ("Paisagem $\mathrm{n}, 3$ ")

Mais que tudo, entretanto, Mário é o andarilho, o poeta-transeunte que esquadrinha a epiderme rugosa e dessemelhante da cidade, experimentando as situaçōes e examinando as faces em que o impacto da modernização imprimiu os sinais de sua voragem, que dispersa energias e concentra tensōes. Ele percorre os meandros tortuosos dos mil caminhos, em busca do contato íntimo que possa revestir de vínculos simpáticos os entes e locais cuja remodelaçāo tecnolögica tornou inatingivelmente alheios. Trata-se de um caminhar sem destino portanto, mas nāo sem destinação, já que é patente o anseio poético pelo resgate de uma humanidade quintessencial dilacerada e que o escritor tenta recoser com pontos curtos, dados pelo movimento contínuo dos seus passos. E lá vai ele, inquieto, olhos vazios tremeluzindo em todas as direçōes:

${ }^{18}$ Blaise Cendrars, Au cocur du monde, Poeisies complètes: 1924-1929, Paris, Gallimard, 1985, pp, 5-90. 
Ruas do meu Sāo Paulo

Onde está o amor vivo,

Onde está?

Caminhos da cidade,

Corro em busca do amigo

Onde está?

Ruas do meu Sāo Paulo,

Amor maior que o cibo

Onde está?

Caminhos da cidade,

Resposta ao meu pedido

Onde está?

Ruas do meu São Paulo,

A culpa do insofrido,

Onde está? [...

"Ruas do Meu São Paulo")

Conquanto seja a fonte do esgarçamento das vivências comunitárias mais calorosas, a metrópole moderna traz consigo o potencial de transformaçōes democráticas, pelas quais seria possivel recuperar a dignidade da cultura popular e confrontar a opressāo dos arrivistas sobre os explorados. Mário de Andrade também busca esse nivelamento igualitário nas suas andanças, atento ao alumbramento latente que cintila em cada concidadão, independentemente de sua condiçâo ou aparência, desde que ele possa ter acesso e deflagrar as inúmeras e imprevisíveis alternativas que a cidade comporta. A sós, em meio à lotaçāo do transporte público, ele olha para o passageiro à sua frente e divaga, sentindo a energia da solidariedade que brota e se transmite entre eles:

Numa cabeleira pesada

Que ondula defronte de mim

No bonde,

Hả reflexos de sol vermelho.

Um calor nasce no meu corpo

Que todo se desfolha em dedos

Amigos

Que eu perco pelas multidōes.

Os reflexos do sol vermelho

ncendeiam as multidōes

Felizes

Que construirão a outra Sāo Paulo [-.]

("Numa cabeleira pesada")

Como vimos, esse otimismo quanto às promessas emancipatórias da grande cidade atingiu seu clímax nos anos que antecederam a Grande Guerra e foi drasticamente revertido a partir dela. Se o primeiro momento foi assinalado por obras que associavam a reforma urbana à transformaçāo social, tais como a jâ mencionada Parade (1917), de Picasso, Apollinaire e Satie ou Le triomphe de Paris (1913), de Robert Delaunay; o momento seguinte revela suas expectativas soturnas em obras como La ville morte (1921), de Korngold; La Hydre (1921), de Maranek; Tambores na noite (1922), de Brecht ou A Nova Babel (1930), de Fortunato Depero. As cidades começam a ser vistas sobretudo como a fonte do delírio tecnológico que desencadeou o cataclisma bélico ou como o campo de luta dos conflitos sociais que ameaçavam arrastar a civilizaçâo para uma guerra civil de proporçóes consequêencias inéditas. É o que se pressente nas imagens ameaçador proporçoes e (1926), de Fritz Lang, nas fotomontagens da série sobre A guerra do de Metropolis de Rodtchenko ou na vertigem do Alarme noturno (1919) de Ge futuro (1930), O que ressalta dessa apreensão sombria da cidade, como umerg Scholz.

O que ressalta dessa apreento o anseio da sua mais um derivativo do temor que ela instila, é o desejo de controle, o anseio da sua mais completa submissão aos imperativos reguladores do planejamento. As imagens que ganham a cena cultural passam a ser os grandes projetos de racionalização funcional e harmonização social de arquitetos e urbanistas comprometidos com o clima espiritual do "rāo social ordem". Era cidade vertical (1924) de espiritual do "retorno à ordem". Era o caso do plano da Cidade vertical (1924), de Ludwig Hilberseimer, do projeto La cité de circulation (1924-1929), de Theo van Doesburg ou, sobretudo, dado seu grande impacto, o célebre Plan voisin (1925), de Le Courbisier pabretudo, Tratava-se de desativar a bomba revolucionária que tiquetaqueava no para Paris. grande cidade, mas também de intensificar seu potencial inclusivo no interior da grande cidade, mas também de intensiticar seu potencial inclusivo pela otimização e aceleraçāo de seus sistemas de fluxo e de gestâo político-funcional. Não era o fim da grande cidade que se pretendia, mas o seu ajuste técnico com vistas a fim crescimento regulado, previsível e estabilizador. As vedetes dos novos viojetas a um por isso os grandes edifícios verticais, os arranha-céus, a geometriajetos eram desenho urbano e de uma malha viária de grande extensão e velocida retilinea do expressas e, é claro, o automóvel. Nenhuma cidade nunca mais foide, as autopistas Em 1934 o sociólogo e urbanista Maurice Halbwach mais foi a mesma.

Em 1934, o sociólogo e urbanista Mram preleção sobre os rumos da nova reforma que prenunciavam os projetos de Albert Speer para a Nova Berlim, encomendados pelo fuher em pessoa. Ponderava ele sobre a capital do Reich,

Grande aglomeração ou grande cidade? Nessa imensa aglomeraçâo, é ainda a estrada de ferro que desenter e separa a cidade

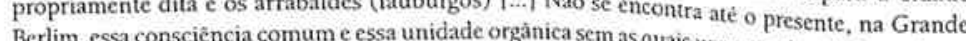
Bertim, essaconscich está privada de todh fora de irradacio, sema sentido pleno do termo, uma cidade. ${ }^{19}$

O diagnóstico preocupante exigia resoluçōes drásticas, era preciso nāo só cortar o mal pela raiz, como receitar-lhe uma terapia de reforço e medidas profiláticas de garantia. A linguagem clínica não é mera fantasia retórica, mas correspondia à mas de clínica como a questâo era vislumbrada e como se propunha atacá deduz das palavras com que Le Corbusier se dirigiu aos seus pares no III Congresso Internacional dos Arquitetos Modernos (CIAM) (1932)

${ }^{19} \mathrm{M}$. Roncayolo, "La ville comme réseau de communications", in J. Dethier; A Guiheux (org. La Ville, art et architecture en Europe 1870-1993, Paris, Centre Pompidou, 1994, p. 222. 
[...] Nós temos a necessidade de conhecer as reações na arquitetura das descobertas da física e da qúdicos. Nos precisamos ainda das certezas da ordem biológica que nos serảo fornecidas pelo médicos. Enfim, nós devemos conhecer como tendem a se regularizar os fenómenos sociais emporâneos . $^{20}$

Ao que o seu colega, o pintor Piet Mondrian, acrescentaria uma dimensāo metafísica e utópica, que partindo dos dados técnicos e científicos se desdobraria até atingir os limites do ideológico e do teológico.

A aplicação das leis do neo-plasticismo destruirá a expressāo trágica do homem da Rua e da Cidade. Através de oposiçōes equilibradas, de relaçōes de medidas (dimensōes), e de cores undamentadas $\mathrm{em}$ relaçōes cromáticas, a alegria física $\mathrm{e}$ moral - condiçāo de saúce - se difundirà Com um pouco de vontade não será impossivel criar um espaço no Ėden..$^{2}$

Na senda desse projeto Mondrian chegaria aos seus famosos diagramas, inspirados nas plantas dos arranha-céus e dos traçados urbanos com que estivera em contacto na sua visita a Nova York, em 1940, traduzidos para uma expressão contacto geometria retilinea rigorosa, composta a partir de grades espaciais e campos cromáticos sustentados por princípios abstratos de harmonia. ${ }^{22}$ Essa expectativa de penetrar num campo de formas transcendentes, através da descoberta de leis abstratas da harmonia, constituía o objetivo por excelência dos neoplasticistas, também definidos por isso como puristas. A inspiraçâo do movimento era obviamente de origem platônica. ${ }^{23}$ Nesse sentido, conquanto seu desempenho se desse no campo estético, ele visava sobretudo um escopo mais elevado, de ordem ética e portanto politica, ao qual a arte deveria servir como um instrumento, uma ferramenta, um meio. Através da arte e da arquitetura se chegaria à República ideal. Le Corbusier estava plenamente ciente dessas coordenadas e as transmitia com a mesma clareza didática aos seus confrades arquitetos do IV CIAM (1933). 1... Poucos sabem ler os planos do urbanismo estabelecidos por signos convencionais, signos
modestos e além do mais destinados a desempenhar esse papel serio: serem a expressão mesma da nossa vida. Nós devemos temer como a peste as "belas representacòes", a maneira dos tapma do Oriente. Estabeleçamos regras segundo nosso ponto de vista a fim de ina a mara dos tapetes Regras que devem ser encontradas para a nossa própria disciplina. Fixcerpion concretos. meios de expressão honestos e o imponhamos ats autoridades?

O circuito da açāo é bern evidente e de sólida tradiçāo platônica, dos pensadores capazes de abstrair as leis - arquitetos e urbanistas nesse caso - às autoridades delas por sobre a população, de cima para baixo. Tal como os diagramas de

${ }^{20}$ A. Guiheux, "Larchitecte de lunivers", in J. Dethier, A. Guiheux (org.) La Ville, artectanthiteuse en Europe 1870-1993, Paris, Centre Pompidou, 1994, p. 298.

"L B. Dorleac, "De-componte Pompidou, 1994, p. 298.

A. Guiheux (org.) La Ville, art et arthitecture en Europe 1870-1993, Prstes teur influence en Europe", in J. Dethier

"T. Threlfall, "Piet Mondrian, an untitled and unknown dri, Centre Pompidou, 1994, p. 86

of the Association of art Historians, v. 12, pp. 229-35, jun. 1978.

"3. Golding: N. Reid Leger, and Purist Pais, Jun. 1978.
Mondrian, os projetos urbanisticos são concebidos e apresentados a partir de uma vista do alto, panóptica, aquela mesma que Michel de Certeau teve que abjurar para encontrar a cidade "lá em baixo", ao nivel das ruas, ao nível dos homens. E Le Corbusier é preclaro em antever de onde viriam as resistências à pureza ética do plano, os arabescos ardilosos da tapeçaria oriental, e por isso adverte o público da reunião: "Esse é um Congresso de técnicos; se há poetas dentre eles - tanto melhor, mas é um caso individual - e o individual nāo pode ser discutido por cem pessoas". ${ }^{24}$ Ele também nāo quer os poetas na sua República.

Os poetas, por seu lado, estavam longe de aceitar os termos da sua exclusāo sob o imperativo do "retorno à ordem". Pelo menos alguns. Era o caso do bando constituído por Tzara, Aragon, Breton, Éluard, Picabia, Fraenkel e Ribemont-Dessaignes, que decidiu fazer, no dia 14 de abril de 1921, às 15 horas, uma visita à Igreja de Saint Julien Le Pauvre, em Paris onde todos moravam. O motivo do passeio a pé era justamente porque o local não possuia nenhum valor histórico, nenhum interesse artístico, qualquer aspecto pitoresco e nem a mais remota carga sentimental. A excursāo constituia portanto um tributo à vida no que ela tem de banal e contingente, ao mesmo tempo que um exercício de relativização, descentralizaçāo e desautorização da percepçāo do espaço urbano. Os poetas queriam com essa experiência provocar um desprendimento da visão oficial e hierarquizante da cidade e criar uma abertura para sua reapropriaçāo crítica e emocional. O passeio foi chamado de "Primeira Visita", e lá chegando, Breton leu um manifesto. O sucesso da iniciativa foi total e novas visitas foram programadas, para o Parque de Buttes-Chaumont, a Gare Saint-Lazare, o Mont du Petit Cadenas, o Canal de LOurcq e o Museu do Louvre. A inclusāo do Louvre deixa claro que a seleçāo pretendia ser aleatória e ignorar quaisquer preconceitos, alinhando no mesmo plano áreas eminentemente populares e o altar máximo da civilização burguesa européia, por exemplo. Em maio de 1924, Breton, Aragon, Morise e Vitrac fizeram um sorteio com nomes de cidades, no qual foram selecionadas Blois e Romorantin, constituindo um trajeto aleatório que o grupo cumpriu a pé. Como resultado dele, Breton escreveu um texto que serviu de prefácio ao Poisson soluble e que veio a se tornar o Primeiro Manifesto do Surrealismo. ${ }^{25}$ Era o desdobramento do projeto da boemia parisiense iniciado pela dérive de Jarry, Picasso e Apollinaire.

Em Sāo Paulo, como em toda parte, o urbanismo se impōe como um esforço para redesenhar a cidade em razão do controle social, da mobilizaçāo funcional e política das grandes massas e da preponderância incontestável do automóvel. O presidente do Automóvel Club, prefeito da capital e futuro governador do Estado, Washington Luis, inaugura a nova tendência, mas o discurso técnico do novo urbanismo será formalizado na segunda metade dos anos 20 sob a égide do engenheiro Prestes Maia. Seu projeto de reforma, denominado Plano Avenidas,

${ }^{24}$ A. Guiheux, "Larchitecte de l'univers", op. cit,, p. 297.

${ }^{25} \mathrm{C}$, Hollevoet; K, Jones; T. Nye, The Power of the City..., op, cit, pp, 25-7. 
data do linal da década e será implementado ao longo dos anos 30 e principalmente 40 , quando assume o cargo de prefeito. O objetivo era em especial racionalizar o traçado viário, agilizar o tráfego, imprimir uma geometria regular à estrutura do espaço urbano, replanejar e distribuir discriminadamente suas funçōes e dotar o conjunto de uma homogeneidade integrada e centralizada. ${ }^{26}$ Poucas vozes ousaram ou puderam resistir a essa redefinição da cidade em razāo de um projeto inspirado na técnica e voltado para as máquinas e o concreto armado. Um dos poucos foi o escritor Alcântara Machado, voltado para os subúrbios e para a população operária e imigrante dos arrabaldes distantes, pantanosos, pestilentos e solenemente ignorados pelas autoridades ${ }^{27}$ Outro era o ensaista e jornalista Sẻrgio Buarque de Holanda, que num conto surrealista narra uma fantasia erótico-errante pelos antigos jardins exuberantes da cidade, tentando fugir do autoritarismo castrador e insensivel dos mandatários da metrópole..$^{28}$

A mais arguta interlocuçāo com o novo contexto porém, uma vez mais, procede da Lira paulistana de Mário de Andrade. No seu longo poema "Meditaçāo sobre o Rio Tietê", de 1944-1945, o poeta faz das tortuosidades do rio o seu arabesco oriental, sua tapeçaria persa traçada sinuosamente por entre a geometria da cidade e a perspectiva linear das estradas de ferro às suas margens. $O$ rio é como uma longa rua, ondulada, incerta e infinita, que ele percorre a esmo, derivando por sobre as águas oleosas e negras como $o$ asfalto, cruzando com destroços e refugos do consumo, apreciando a vida variada das margens, a vegetação das várzeas ribeirinhas, os casebres pobres, os animais silvestres e de criação, o tráfego pesado das pontes, a fila sem fim das fábricas, os operários apinhados nas estaçŏes de trem, o perfil arrogante das colinas centrais, onde vicejam os arranha-céus, a serra verdejante na margem oposta, adentrando para os sertōes interiores. Cada presença na superfície do rio, cada visāo nas margens evocam ressonâncias na sua memória, repercutem dentre suas fantasias e revolvem o âmago de seus desejos, mas cada vez mais, insistentemente, revolvem suas frustraçōes e a amargura pelo fracasso do sonho democrático da metrópole que nāo se cumpriu, o desgosto pelo conformismo das formas fixas que congelaram e condenaram o livre fluxo das expectativas e solidificaram a itinerância imprevisível dos destinos. É noite densa e escura, o poeta olha compassivo para as águas que rolam aos seus pés, encarapitado no alto da Ponte das Bandeiras, símbolo mítico da cidade dos conquistadores e elo entre o centro rico e os bairros proletários da zona norte:

Ė noite. E tudo é noite. Debaixo do arco admirável

Da Ponte das Bandeiras o rio

Murmura num banzeiro de agua pesada e oliosa,

E noite e tudo é noite. Uma ronda de sombras,

Soturnas sombras, enchem de noite tāo vasta

O peito do rio, que é como si a noite fosse água,

${ }^{26}$ Samuel Kruchin, "Prestes Maia, o sentido do urbano" in Oculum, revista universitaria de arquitetura, urbanismo c cultura, n. 4, nov. 93. Campinas, FAUPUCCAMP, pp. 76-81.

27 António de Alcantara Machado, Novelas paulistanas, Sảo Paulo/Belo Horizonte, Edusp/tatiaia, 1988. ${ }^{28}$ Sérgio Buarque de Holanda, “A viagem a Nápoles", Revista do Brasil, ano 3, n. 6, 87, número especial dedicado a Sérgio Buarque de Holanda, pp. 18-26.

\author{
Água noturna, noite líqüida, alogando de apreensōes \\ As altas torres do meu coraçāo exausto. De repente \\ O ólio das águas recollhe en cheio luzes trêmulas, \\ E um susto. E num momento o rio \\ Esplende em luzes inumeràveis, lares, paläcios e ruas, \\ Ruas, ruas, por onde os dinosauros caxingam \\ Agora arranhacéus valentes donde saltam \\ Os bichos blau e os punidores gatos verdes, \\ Em cânticos, em prazeres, em trabalhos e fábricas, \\ Luzes e glória. É a cidade... É a emaranhada forma \\ Humana corrupia da vida que muge e se aplaude. \\ Ese aclama e se falsifica e se esconde. E deslumbra. \\ Ese aclama e se falsilica e se esconde. E deslumbra. \\ Mas e urn momento só, Logo o rio escurece de no \\ Está negro, As águas oliosas e pesadas se aplacam

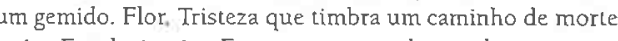 \\ È noite, E tudo é noite, E o meu coraçāo devastado \\ É um rumor de germes insalubres pela noite insone e humana \\ Meu rio, meu Tietê, onde mc levas? \\ Sarcástico rio que contradizes o curso das àguas \\ E te alastas do mar e te adentras na terra dos homens. \\ Onde me queres levar?. \\ $[\ldots]$
}

Mário de Andrade pōe-se entāo a glosar a condiçāo peculiar do Rio Tietê, que por um capricho geográfico corre no sentido oposto ao do mar, adentrando para os sertōes interiores, tendo por isso servido como o eixo líqüido através do qual se fez a conquista do território brasileiro. A partir dessa imagem invasora, o rio evoca o próprio processo da colonização do país, o apresamento e escravização dos indigenas e o fato de que ele mesmo é, agora, submetido à captaçāo e represamento das suas águas para as novas usinas hidrelétricas que suprem a metrópole. O Tieté aparece assim convertido num rio escravo, dominado e brutalizado, emblema fluido do povo oprimido vivendo às suas margens e tratado pelos potentados como uma massa amorfa, empurrada à força numa longa coluna errante de malsinados privados de identidade e destino, proibidos para sempre de encontrarem as imensidōes redentoras do oceano aberto.

[...] Ven de träs o estirāo. É tão soluçante e tão longo, E lá na curva do rio vềm outros estirōes e mais outros, E lã na Irente são outros, todos soluçantes e presos Por curvas que serão sempre apenas as curvas do rio. Há de todos os assombros, de todas as purezas e martírios Nesse rolo torvo das àguas. Meu Deus! meu Rio! Como é possivel a torpeza da enchente dos homens! Quem pode compreender o escravo macho

E multirnilenar que escorre e sofre e mandado escorre

Entre injustiça e impiedacle, estreitado

Nas margens e nas areias das praias sequiosas?

Elas bebem e bebem. Não se fartam, deixando com desespero

Que o resto do galé aquoso ultrapasse esse dia,

Pra ser represado e bebido pelas outras areias

Das praias adianıe, que também dominam, aprisionam e mandam 
A trágica sina do rolo das águas, e dirigem

O leito impassivel da injustiça e da impiedade.

Ondas, a multidāo, o rebanho, o rio, meu rio, um rio

Que sobe! Fervilha e sobe! E se adentra fatalizado, e em vez

De ir se alastrar arejado nas liberdades oceânicas,

Em vez se adentra pela terra escura e ávida dos homens,

Dando sangue e vida a beber. $\mathrm{E}$ a massa liquida

Da multidāo onde tudo se esmigalha e se iguala,

Rola pesada e oliosa, e rola num rumor surdo.

E rola mansa, amansada imensa eterna, mas

No eterno imenso rigido canal da estulca dor

Na sua longa peregrinaçāo pelo rio, com o rio, como o rio, Mário de Andrade sente as formas se dissolverem, os valores se conspurcarem, vidas serem consumidas e disperdiçadas sob a mesma displicência que polui, destrata, serviliza e condena o rio à abjeçāo e ao abandono. O poeta-errante no seu barco-fantasma se sente incitado a desistir, a abandonar sua busca inútil e renegar seus portos quiméricos, a pular fora da memória e enxugar a umidade dos seus desejos, rumando para o ponto da margem de onde pudesse embarcar num veículo expresso, em curso retilíneo para o circuito mecânico da grande cidade. Algo porém o impede. A compulsão talvez, sua crônica compulsāo a vagar, assinalando com a trajetória instavel do seu deslocamento uma coreografia que congregasse o vário e o inconstante num mesmo abraço erótico e num mesmo ritmo aliciante. Su frustraçāo, sua amargura, seu amor rejeitado entretanto, só tem esse mesmo destino - de se mesclar com as correntes turvas e amaldiçoadas do rio-emblema, fundindo num só destino, o destino de todos, águas e mágoas fluindo à deriva.

Da água, e eu bailo de ignorâncias inventivas

Meu baile é solto como a dor que range, meu

Baile é lāo vário que possui mil sambas insonhados!

Eu converteria o humano crime num baile mais denso

Que essas ondas negras de água pesada e oliosa

..... E tudo é noite! E os meus olhos sāo noite

Eu nāo enxergo siquer as barcaças na noite.

So a enorne cidade. E a cidade me chama e pulveriza,

E me disfarça numa queixa flébil e comedida

1... Rio, o que eu posso fazer!.

Rio, meu rio... mas porèm hä-de haver com certeza

Outra vida melhor do outro lado de lá

Da serra! E hei-de guardar silêncio!

O que eu posso fazer!... hei-de guardar silêncio

Deste amor mais perleito do que os homens?

Eu me acho tão cansado em meu furor.

As águas apenas murmuram hostis, água vil mas turrona paulista

Que sobe e se espraia, levando auroras represadas

Para o peito dos sofrimentos dos hoinens.

... e tudo é noite. Sob o arco adinirável

Da Ponte das Bandeiras, morta, dissoluta, fraca,

Una lágrima apenas, uma lägrima

Eu sigo alga escusa nas águas do meu Tietê. 